\title{
The relationship between liquidity risk and credit risk in Islamic banking industry of Iran
}

\author{
Hashem Nikomaram $^{a^{*}}$, Mehdi Taghavi ${ }^{a}$ and Somayeh Khalili Diman ${ }^{b}$
}

${ }^{a}$ Professor and Faculty member, Department of Financial Management, Science and Research branch, Islamic Azad University (IAU), Tehran, Iran ${ }^{b}$ M.Sc. Student, Department of Financial Management, Science and Research branch, Islamic Azad University (IAU), Tehran, Iran

\section{H R O N I C L E A B S T R A C T}

Article history:

Received October 28, 2012

Received in revised format

18 February 2013

Accepted 19 February 2013

Available online

February 272013

Keywords:

Liquidity Risk

Credit Risk

Financial Crisis

Bank Size

Bank Ownership

\begin{abstract}
An integrated risk management is a process, which enables banks to measure and manage all risks, simultaneously. The recent turbulent chaos on banking industry has increase the relative importance of risk management, more than before. This paper investigates the relationship between credit risk and liquidity risk among Iranian banks. The proposed study includes all private and governmental banks as population over the period 2005-2012. The results Pearson correlation has disclosed a positive and meaningful relationship between credit and liquidity risks. Bank size also impacts on two mentioned risk factors but we there seems to be no relationship between financial chaos and type of ownership with risk factors.
\end{abstract}

\section{Introduction}

During the past two decades, there have been significant changes on banking industry in the world due to financial crisis in this sector in 2008 (Lando, 2009; Fiordelisi et al., 2010). Many banking officials attempt to put more restrictions on giving loan to business owners in an attempt to prevent any trouble making issue. There are also various studies on relationship between different banks' characteristics such as size, market capitalization, etc. (Wong et al., 2008). Salas and Saurina (2002), for instance, investigated credit risk in two institutional regimes by studying two Spanish commercial and savings banks. Dičevska (2012) performed an investigation on credit risk and established a system for credit risk management in changing economic conditions in Macedonian banks. 
Cifuentes et al. (2005) investigated liquidity risk in a system of interconnected financial institutions when these institutions were under regulatory solvency constraints and marked their assets to market. According to their survey, when the market's demand for illiquid assets was less than perfectly elastic, sales by distressed institutions depressed the market prices of such assets. They studied the theoretical basis for contagious failures, quantified them through simulation exercises and reported that liquidity requirements on institutions could be as efficient as capital requirements in forestalling contagious failures.

Michalak and Uhde (2012) provided some empirical evidence that credit risk securitization had a negative effect on the issuing banks' financial soundness. For this purpose, they used a unique sample of 749 cash and synthetic securitization transactions issued by 60 stock-listed bank holdings in the EU-13 plus Switzerland over the period over the period 1997-2007. They reported a negative influence of securitization on bank profitability and capital environment as well as a positive relationship between securitization and the issuing bank's return volatility. They underlined that the decision by the Basel Committee to enhance the new Basel III framework in the field of securitization was a step in the right direction.

\section{The proposed study}

The proposed study of this paper considers the effects of three variables, namely ownership type, bank size and financial crises on two risk components including credit and liquidity risks. Fig. 1. shows details of our proposed model.

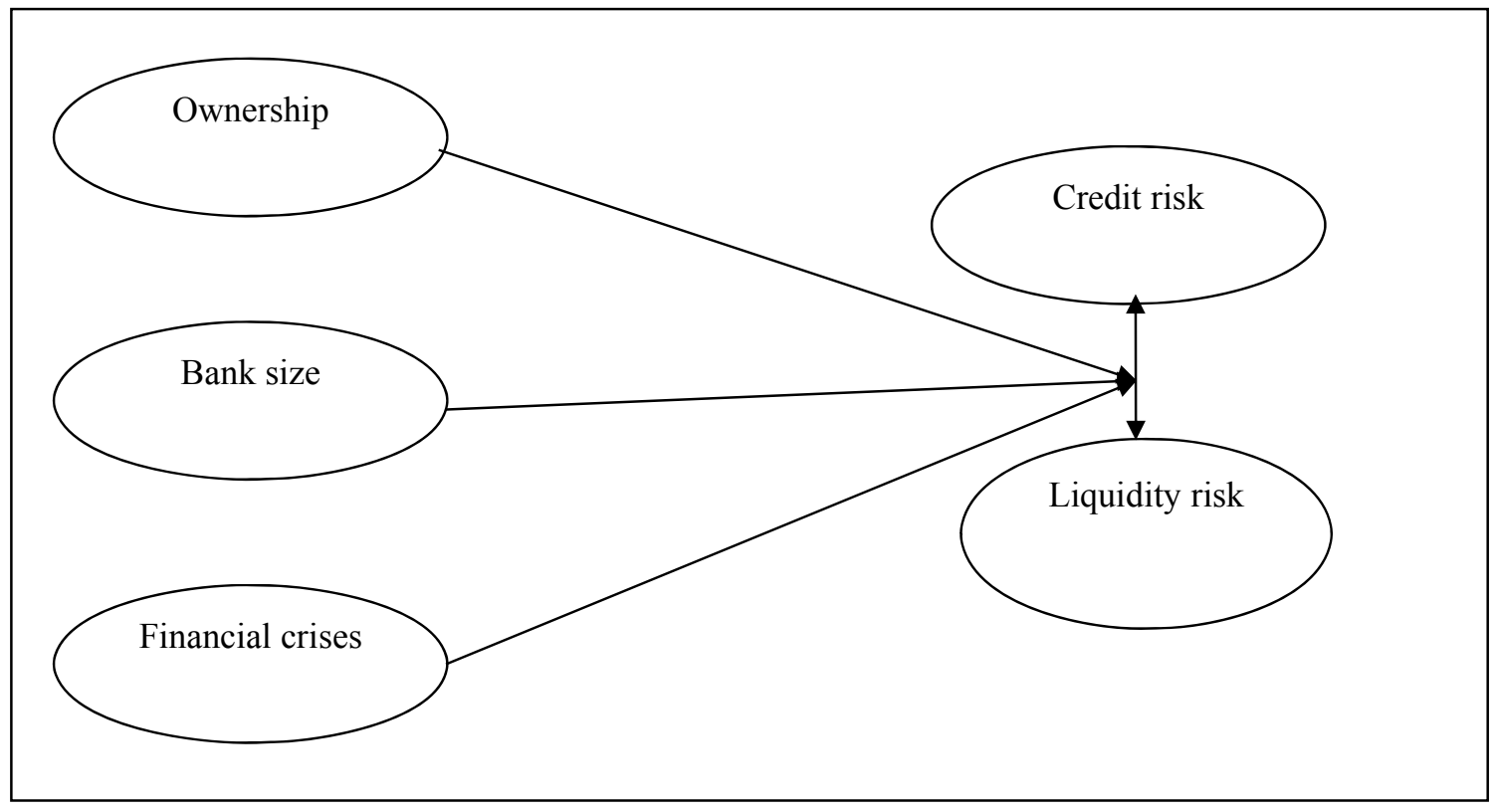

Fig. 1. The proposed framework of the study

According to Fig. 1 all components are calculated as follows,

Liquidity risk: This ratio is calculated as follows,

Liquidity risk $(L R)=[($ Demand Deposits + Transaction Deposits + Brokered Deposits + NOW Accounts + Unused Loan Commitments)-(Cash + Currency \& Coin + Trading Assets + Fed Funds

Purchased + Commercial Paper + Securities available for Sale ) \pm Net Inter-Bank Lending Position \pm Net Inter-Bank Acceptances \pm Net Derivative Position]/Total Assets 
Any positive value for liquidity risk (LR) indicates that bank cannot guarantee incidents.

\section{Berger-Bouwman (BB) measure}

Berger-Bouwman (BB) factor is calculated as Cat Fat/Total Assets while credit risk (CR) is measured as follows,

$$
C R_{Z-\text { Score }}=\ln \left(R O A+C A P / \sigma_{R O A}\right),
$$

where $R O A$ is return on assets, $C A P$ represents the ratio of total equities on total assets and $\sigma_{R O A}$ is the standard deviation of $R O A$. Obviously, the higher value represents the higher risk. Credit risk (CR) ratio can also be calculated as follows,

$$
\begin{aligned}
& \text { Credit Risk }(\mathrm{CR})=\frac{\text { Loan charfe -Offs }}{\mathrm{t}}-\text { Loan Recoveries }_{\mathrm{t}} \\
& \mathrm{CR}_{\text {Z-Soore }}=\ln \frac{\mathrm{ROA} \text { Loss }+ \text { Capital ratio }}{\sigma_{\text {ROA }}},
\end{aligned}
$$

In this study, bank ownership is a dummy variable, which is equal to zero for governmental banks and one for private banks. Bank size is also calculated by taking the log of total assets and Financial crises is also a dummy variable, which is equal to zero when there is no crises and one during the financial turbulence. In our study, there were 144 observations and $45.8 \%$ of the data were associated with governmental banks while $54.2 \%$ of the observations were associated with private banks. In addition, $37.5 \%$ of the observations belong to before crisis and $62.5 \%$ of the data were associated with after crisis. Table 1 demonstrates some basic statistics on bank size.

\section{Table 1}

Basic statistics associated with bank size

\begin{tabular}{lllllllll}
\hline $\begin{array}{l}\text { Independent } \\
\text { variable }\end{array}$ & $\begin{array}{l}\text { Number of } \\
\text { observations }\end{array}$ & Mean & $\begin{array}{l}\text { Standard } \\
\text { deviation }\end{array}$ & Variance & Skewness & Kurtisos & $\begin{array}{l}\text { Deviations } \\
\text { Skewness }\end{array}$ & Kurtisos \\
\hline Bank size & 144 & 11.18 & 1.47 & 2.16 & -0.39499 & -0.532 & -1.955 & -1.325 \\
\hline
\end{tabular}

According to the results of Table 1, there are 144 observations where banks-size maintains an average of 11.18 with standard deviation of 1.47 and standard deviation of 2.161 and it seems to be normally distributed. Table 2 demonstrates the results of CRz-score,

Table 2

Basic statistics associated with CRz-score

\begin{tabular}{lllllllll}
$\begin{array}{l}\text { Independent } \\
\text { variable }\end{array}$ & $\begin{array}{l}\text { Number of } \\
\text { observations }\end{array}$ & Mean & $\begin{array}{l}\text { Standard } \\
\text { deviation }\end{array}$ & Variance & Skewness & Kurtisos & $\begin{array}{l}\text { Deviations } \\
\text { Skewness }\end{array}$ & Kurtisos \\
\hline CRz-score & 144 & 2.390 & 1.016 & 1.034 & 0.143 & 2.239 & 0.711 & 5.826 \\
\hline
\end{tabular}

The results of Table 2 indicate that data do not seem to be normally distributed. Table 3 shows similar results for CR variable.

\begin{tabular}{|c|c|c|c|c|c|c|c|c|}
\hline $\begin{array}{l}\text { Independent } \\
\text { variable }\end{array}$ & $\begin{array}{l}\text { Number of } \\
\text { observations }\end{array}$ & Mean & $\begin{array}{l}\text { Standard } \\
\text { deviation }\end{array}$ & Variance & Skewness & Kurtisos & $\begin{array}{l}\text { Deviations } \\
\text { Skewness }\end{array}$ & Kurtisos \\
\hline $\mathrm{CR}$ & 117 & 2.430 & 4.445 & 23.336 & 4.856 & 26.231 & 21.717 & 59.119 \\
\hline
\end{tabular}

\section{Table 3}

Basic statistics associated with CR 
The results of Table 3 for CR indicate that the results are away from normal distribution. Table 4 presents the same descriptive results for variable LR and we could make similar conclusion that LR was not normally distributed.

Table 4

Basic statistics associated with LR

\begin{tabular}{lllllllll}
\hline $\begin{array}{l}\text { Independent } \\
\text { variable }\end{array}$ & $\begin{array}{l}\text { Number of } \\
\text { observations }\end{array}$ & Mean & $\begin{array}{l}\text { Standard } \\
\text { deviation }\end{array}$ & Variance & Skewness & Kurtisos & $\begin{array}{l}\text { Deviations } \\
\text { Skewness }\end{array}$ & Kurtisos \\
\hline LR & 114 & -0.26 & 0.283 & 0.052 & -1.188 & 0.742 & -5.884 & 1.850 \\
\hline
\end{tabular}

In order to have a better understanding on the nature of data, we use Kolmogorov-Smirnov and Shapiro-Wilk tests and Table 5 demonstrates the results of our experiment for 144 observations.

Table 5

The results of Kolmogorov-Smirnov and Shapiro-Wilk tests

\begin{tabular}{lcccc}
\hline \multirow{2}{*}{ Variable } & \multicolumn{2}{c}{ Kolmogorov-Smirnov } & \multicolumn{3}{c}{ Shapiro-Wilk } & Sig. \\
\hline Bank size & Stat. & Sig. & .974 & .021 \\
CR & .072 & .193 & .947 & .000 \\
CR & .105 & .003 & .389 & .000 \\
LR & .310 & .000 & .812 & .000 \\
LR & .179 & .000 & .703 & .000 \\
\hline BB & .326 & .000 & .00 & \\
\hline
\end{tabular}

As we can observe from the results of Table 5, only bank size is normally distributed and other variables are not normally distributed when the level of significance is five percent.

\subsection{The relationship between credit and liquidity risks}

In this section, we present details of our findings for the relationships between different variables based on Pearson correlation ratios. Table 6 demonstrates the results of our survey.

Table 6

The summary of statistical observations for the implementation of Pearson correlation ratio

\begin{tabular}{|c|c|c|c|c|c|}
\hline Variable & & $\mathrm{LR}_{\mathrm{BB}}$ & LR & $\mathrm{CR}$ & $\mathrm{CR}_{\text {Z-Score }}$ \\
\hline \multirow{3}{*}{$\mathrm{CR}_{\mathrm{Z} \text {-Score }}$} & Pearson correlation & -.179 & -.194 & -.211 & 1 \\
\hline & $\mathrm{P}$-value & .032 & .020 & .022 & \\
\hline & No. & 144 & 144 & 117 & 144 \\
\hline \multirow{3}{*}{$\mathrm{CR}$} & Pearson correlation & .259 & .201 & 1 & -.211 \\
\hline & $\mathrm{P}$-value & .005 & .030 & & .022 \\
\hline & No. & 117 & 117 & 117 & 117 \\
\hline \multirow{3}{*}{ LR } & Pearson correlation & .406 & 1 & .201 & -.194 \\
\hline & P-value & .000 & & .030 & .020 \\
\hline & No. & 144 & 144 & 117 & 144 \\
\hline \multirow{3}{*}{$\mathrm{LR}_{\mathrm{BB}}$} & Pearson correlation & 1 & .406 & .259 & -.179 \\
\hline & P-value & & .000 & .005 & .032 \\
\hline & No. & 144 & 144 & 117 & 144 \\
\hline
\end{tabular}

In this study credit risk is measured based on two attributes of CR and CRz-score. In addition, liquidity risk is calculated based on two attributes of $L R$ and $L_{B B}$. Based on the results of Table 6, we can observe that there is a meaning and reverse relationship between CRz-score and LR when the level of significance is five percent. There are also meaningful and reverse relationships between CRz-score and LR, between CRz-score and LR, when the level of significance is five percent. However, the relationship between $\mathrm{CR}$ and $\mathrm{LR}$ and between $\mathrm{CR}$ and $\mathrm{LR}_{\mathrm{BB}}$ are meaningful but positive when the level of significance is five percent. 


\subsection{The results of Pearson correlation with bank size as control variable}

We have accomplished the same results as explained in previous section when there is an additional variable, bank size, and Table 7 demonstrates the results of our survey.

Table 7

The results of Pearson correlation ratios

\begin{tabular}{|c|c|c|c|c|c|}
\hline \multirow[b]{2}{*}{ Variable } & & \multicolumn{4}{|c|}{ Bank size } \\
\hline & & $\mathrm{LR}_{\mathrm{BB}}$ & LR & $\mathrm{CR}$ & $\mathrm{CR}_{\mathrm{Z} \text {-Score }}$ \\
\hline \multirow{3}{*}{$\mathrm{CR}_{\text {Z-Score }}$} & Pearson correlation & -.046 & -.062 & -.203 & 1.000 \\
\hline & P-value & .626 & .510 & .029 & . \\
\hline & No. & 114 & 114 & 114 & 0 \\
\hline \multirow{3}{*}{$\mathrm{CR}$} & Pearson correlation & .281 & .193 & 1.000 & -.203 \\
\hline & P-value & .002 & .038 & . & .029 \\
\hline & No. & 114 & 114 & 0 & 114 \\
\hline \multirow{3}{*}{ LR } & Pearson correlation & .467 & 1.000 & .193 & -.062 \\
\hline & P-value & .000 & & .038 & .510 \\
\hline & No. & 114 & 0 & 114 & 114 \\
\hline \multirow{3}{*}{$\mathrm{LR}_{\mathrm{BB}}$} & Pearson correlation & 1.000 & .467 & .281 & -.046 \\
\hline & P-value & . & .000 & .002 & .626 \\
\hline & No. & 0 & 114 & 114 & 114 \\
\hline
\end{tabular}

The results of Table 7 show that in the presence of bank size, the relationship between CRz-score and LR is reduced from -0.194 to -0.062 and although the relationship is still negative but it is not statistically significance. The same result holds for the relationship between CRz-score and $\mathrm{LR}_{\mathrm{BB}}$ and we observe that the relationship is reduced from -0.179 to -0.046 but it is not statistically significance. However, the positive relationship between $\mathrm{CR}$ and $\mathrm{LR}_{\mathrm{BB}}$ has been increase from 0.259 to 0.281 and it is still significant even when the level of significance is one percent.

2.3. The results of Pearson correlation ratio for credit and liquidity risks between private and governmental banks

Table 8

The results of Pearson correlation ratios for private and governmental ownership

\begin{tabular}{|c|c|c|c|c|c|c|}
\hline & & & & & & \\
\hline & & & $\mathrm{LR}_{\mathrm{BB}}$ & LR & $\mathrm{CR}$ & $\mathrm{CR}_{\text {Z-Score }}$ \\
\hline & & Pearson correlation & -.326 & -.270 & -.191 & 1 \\
\hline & $\mathrm{CR}_{\text {Z-Score }}$ & P-value & .008 & .028 & .162 & \\
\hline & & No. & 66 & 66 & 55 & 66 \\
\hline & & Pearson correlation & .052 & .220 & 1 & -.191 \\
\hline 䒿 & $\mathrm{CR}$ & P-value & .707 & .107 & & .162 \\
\hline $\bar{\Xi}$ & & No. & 55 & 55 & 55 & 55 \\
\hline 苛 & & Pearson correlation & .812 & 1 & .220 & -.270 \\
\hline 范 & LR & P-value & .000 & & .107 & .028 \\
\hline & & No. & 66 & 66 & 55 & 66 \\
\hline & & Pearson correlation & 1 & .812 & .052 & -.326 \\
\hline & $\mathrm{LR}_{\mathrm{BB}}$ & P-value & & .000 & .707 & .008 \\
\hline & & No. & 66 & 66 & 55 & 66 \\
\hline & & Pearson correlation & -.095 & -.134 & -.229 & 1 \\
\hline & $\mathrm{CR}_{\text {Z-Score }}$ & P-value & .410 & .243 & .073 & \\
\hline & & No. & 78 & 78 & 62 & 78 \\
\hline & & Pearson correlation & .0415 & .159 & 1 & -.229 \\
\hline & CR & P-value & .001 & .216 & & .073 \\
\hline 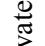 & & No. & 62 & 62 & 62 & 62 \\
\hline 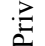 & & Pearson correlation & .198 & 1 & .159 & -.134 \\
\hline & LR & P-value & .083 & & .216 & .243 \\
\hline & & No. & 78 & 78 & 62 & 78 \\
\hline & & Pearson correlation & 1 & .198 & .415 & -.095 \\
\hline & $\mathrm{LR}_{\mathrm{BB}}$ & P-value & & .083 & .001 & .410 \\
\hline & & No. & 78 & 78 & 62 & 78 \\
\hline
\end{tabular}


The results of Table 8 show that the relationship between CRz-score and LR is negative for governmental banks and it is statistically significance when the level of significance is five percent. In addition, the relationship between CRz-score and LR is negative for private banks but it is not statistically significance when the level of significance is five percent. There is also a negative and meaningful relationship between CRz-score and $\mathrm{LR}_{\mathrm{BB}}$ between governmental banks when the level of significance is one percent. Despite the fact that the same relationship holds for governmental banks, the relationship is not statistically significance. The relationship between CR and LR is positive in governmental and private banks but it is not statistically significance. Finally, in spite the fact that the relationship between $\mathrm{CR}$ and $\mathrm{LR}_{\mathrm{BB}}$ is not statistically significance for governmental banks, it is statistically significance for private banks. In order to compare the relative effect of various factors between governmental and private banks we have calculated Fisher correlation ratio based on the following

$\left.z_{o b}=\left(z_{r 1}-z_{r 2}\right) / \sqrt{\left(1 / n_{1}\right.}-3\right)+\left(1 / n_{2}-3\right)$

The result of Table 9, none of $\mathrm{z}$ value is not statistically significance leaving us to conclude that ownership type does not play an important role on different risk components.

Table 9

Statistical observations for $\mathrm{z}$ value

\begin{tabular}{llllllll}
\hline & Number & \multicolumn{2}{l}{ Pearson correlation } & Fisher & \multicolumn{2}{c}{$Z$} \\
\cline { 2 - 6 } & Private & Gov. & Private & Gov. & Private & Gov. & 0.792868 \\
\hline LR with CRz-score & 78 & 66 & -0.134 & -0.27 & 0.1338 & 0.2693 & 1.350508 \\
LR $_{\text {BB }}$ with CRz-score & 78 & 66 & -0.095 & -0.326 & 0.0953 & 0.3261 & 0.327007 \\
CR with LR & 62 & 55 & 0.159 & 0.22 & 0.1583 & 0.2205 & -1.90999 \\
\hline CR with LR & 62 & 55 & 0.415 & 0.052 & 0.4153 & 0.052 & \\
\hline
\end{tabular}

\subsection{The results of Pearson correlation before and after crises}

\section{Table10}

The results of Pearson correlation ratios before and after crisis

\begin{tabular}{|c|c|c|c|c|c|c|}
\hline & & & & & & \\
\hline & & & $\mathrm{LR}_{\mathrm{BB}}$ & LR & $\mathrm{CR}$ & $\mathrm{CR}_{\text {Z-Score }}$ \\
\hline & & Pearson correlation & -.085 & -.367 & -.006 & 1 \\
\hline & $\mathrm{CR}_{\text {Z-Score }}$ & P-value & .541 & .006 & .972 & \\
\hline & & No. & 54 & 54 & 35 & 54 \\
\hline & & Pearson correlation & .140 & .448 & 1 & -.006 \\
\hline$\frac{n}{n}$ & CR & P-value & .421 & .007 & & .972 \\
\hline$\overline{0}$ & & No. & 35 & 35 & 35 & 35 \\
\hline ర్ర & & Pearson correlation & .306 & 1 & .448 & -.367 \\
\hline$\ddot{D}$ & LR & P-value & .025 & & .007 & .006 \\
\hline & & No. & 54 & 54 & 35 & 54 \\
\hline & & Pearson correlation & 1 & .306 & .140 & -.085 \\
\hline & $\mathrm{LR}_{\mathrm{BB}}$ & P-value & & .025 & .421 & .541 \\
\hline & & No. & 54 & 54 & 35 & 54 \\
\hline & & Pearson correlation & -.205 & -.135 & -.236 & 1 \\
\hline & $\mathrm{CR}_{\text {Z-Score }}$ & P-value & .052 & .205 & .033 & \\
\hline & & No. & 90 & 90 & 82 & 90 \\
\hline & & Pearson correlation & .277 & .164 & 1 & -.236 \\
\hline$\frac{n}{n}$ & $\mathrm{CR}$ & P-value & .012 & .141 & & .033 \\
\hline E) & & No. & 82 & 82 & 82 & 82 \\
\hline$\dot{\Xi}$ & & Pearson correlation & .444 & 1 & .164 & -.135 \\
\hline 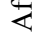 & LR & P-value & .000 & & .141 & .205 \\
\hline & & No. & 90 & 90 & 82 & 90 \\
\hline & & Pearson correlation & 1 & .444 & .277 & -.205 \\
\hline & $\mathrm{LR}_{\mathrm{BB}}$ & P-value & & .000 & .012 & .052 \\
\hline & & No. & 90 & 90 & 82 & 90 \\
\hline
\end{tabular}


According to the results of Table 10, there is a reverse and meaningful relationship between CRzscore and LR before crisis when the level of significance is one percent but this relationship is not statistically significance after crisis. The relationship between CRz-score and $\mathrm{LR}_{\mathrm{BB}}$ is not significance either before or after the crisis. The relationship between CR and LR is positive and meaningful before crisis but it is not meaningful after crisis. The relationship between $C R$ and $L_{\mathrm{BB}}$ is not statistically significance before crisis but it is statistically significance after crisis happens.

In order to compare the relative effect of various factors between governmental and private banks we have calculated Fisher correlation ratio based on the following

$\left.z_{o b}=\left(z_{r 1}-z_{r 2}\right) / \sqrt{\left(1 / n_{1}\right.}-3\right)+\left(1 / n_{2}-3\right)$

The results of Table 11, none of $\mathrm{z}$ values is not statistically significance leaving us to conclude that crisis does not play an important role on different risk components.

Table 11

Statistical observations for $\mathrm{z}$ value before and after crisis

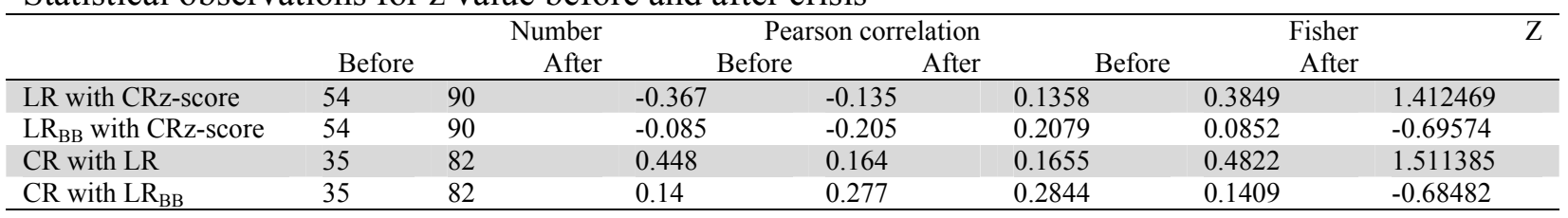

\section{The results}

In this section, we summarize the results of our survey for four hypotheses of this survey. Next, we first present the results of our investigation on four various types of hypotheses.

\subsection{The results of testing four hypotheses}

\subsubsection{The first hypothesis: The relationship between credit and liquidity risk components}

The first hypothesis of this survey considers whether there is a positive and meaningful relationship between credit and liquidity risk. The following summarizes the results of our survey,

$\left\{\begin{array}{l}r \leq 0 \\ r>0\end{array} \mapsto r_{L R, Z-S c o r e}=-0.194, \quad p=0.02, \quad p_{o b}=0.02<p_{o c}=0.05\right.$

As we can observe from the results, there is a meaningful relationship between these two variables, the negative sign is consistent with our hypothesis since a reduction in risk will increase the credit and we can confirm the first hypothesis. Similarly, we perform the following test between two variables $\mathrm{LR}_{\mathrm{BB}}$ and $\mathrm{Z}$-score as follows,

$\left\{\begin{array}{l}r \leq 0 \\ r>0\end{array} \mapsto r_{B B, Z \text {-Score }}=-0.179, \quad p=0.03, \quad p_{o b}=0.03<p_{o c}=0.05\right.$

As we can observe, there are similar results and we can confirm there is a meaningful relationship between these two variables when the level of significance is five percent. In addition, the relationship between LR and CR as well as between $\mathrm{LR}_{\mathrm{BB}}$ and $\mathrm{CT}$ are meaningful when the level of significance is five percent and the results are summarized as follows,

$\left\{\begin{array}{l}r \leq 0 \\ r>0\end{array} \mapsto r_{L R, C R}=0.201, \quad p=0.03, \quad p_{o b}=0.03<p_{o c}=0.05\right.$ 
$\left\{\begin{array}{l}r \leq 0 \\ r>0\end{array} \mapsto r_{B B, C R}=0.259, \quad p=0.005, \quad p_{o b}=0.005<p_{o c}=0.05\right.$

3.1.2 The second hypothesis: The effect of ownership on the relationship between credit and liquidity risk

The results of investigating the effect of ownership on two risks of LR and CRz-score are examined as follows,

$\left\{\begin{array}{l}r_{L R, Z-S c o r e, \text { Governmental }}=r_{L R, Z-S c o r e} \text {, Private } \\ r_{L R, Z-S c o r e, \text { Governmental }} \neq r_{L R, Z-S c o r e, \text { Private }}\end{array} \mapsto z_{o b}=0.792<1.96\right.$

The results indicate that ownership does not have any impact on two risks of LR and CRz-score when the level of significance is five percent. Similar investigation has been performed between $L_{\mathrm{BB}}$ and CRz-score and the result is $Z o b=1.350<1.96$ and this confirms that ownership does not have any impact on LR and CRz-score when the level of significance is five percent. The same conclusions hold for the effect of ownership for the relationships of LR and CR as well as $L_{B B}$ and CR when the level of significance is five percent. In other words, ownership does not play important role on these risk components.

\subsubsection{The third hypothesis: The effect of bank size on the relationship between credit and liquidity risk}

The results of investigating the effect of bank size on two risks of LR and CRz-score are examined as follows,

$\left\{\begin{array}{l}r=0 \\ r \neq 0\end{array} \mapsto r_{L R, Z S c o r e, \text { Bank size }}=-0.062, p=0.51, p_{o b}=0.51>p_{o c}=0.05\right.$

The result of Pearson correlation ratio does not indicate that bank size has any impact on the relationship between LR and CRz-score when the level of significance is five percent. Similarly, the results of investigating the effect of bank size on the relationship between $L_{\mathrm{BB}}$ and CRz-score is $\mathrm{p}_{\mathrm{ob}}=0.62>\mathrm{p}_{\mathrm{oc}}=0.05$, which means there is no meaningful relationship. However, the effect of bank size on relationship between CR and LR as well as $C R$ and $L R_{B B}$ are equal to $p_{o b}=0.03<p_{o c}=0.05$ and $\mathrm{p}_{\mathrm{ob}}=0.002<\mathrm{p}_{\mathrm{oc}}=0.05$, which means the bank size influences these two pairs of risk factors, significantly.

\subsubsection{The fourth hypothesis: The effect of crisis on the relationship between credit and liquidity risk}

The results of investigating the effect of ownership on two risks of LR and CRz-score are examined as follows,

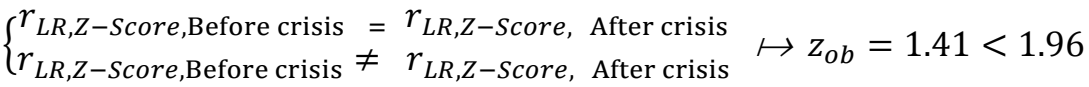

The results indicate that crisis does not have any impact on two risks of LR and CRz-score when the level of significance is five percent. Similar investigation has been performed between $L_{\mathrm{BB}}$ and CRz-score and the result is Zob $=-0.69<1.96$ and this confirms that crisis does not have any impact on LR and CRz-score when the level of significance is five percent. The same conclusions hold for the effect of ownership for the relationships of LR and CR as well as LR $\mathrm{BB}_{\mathrm{BB}}$ and CR when the level of significance is five percent. In other words, crisis does not play important role on these risk components.

\subsection{Other results}

We have also performed regression analysis on relationship between the effects of CRz-scor, $\mathrm{LR}_{\mathrm{BB}}$, LR and CR as independent variables and bank size, crisis and ownership as dependent variables. Table 12 shows the results of testing the first regression model where LR is the dependent variable. 
Table 12

The results of regression analysis for the first model when LR is dependent variable

\begin{tabular}{lccccc}
\hline Variable & \multicolumn{2}{c}{ Non-standard coefficients } & \multicolumn{2}{c}{ Standard coefficients } \\
& $\mathrm{B}$ & Standard dev. & $\mathrm{B}$ & t-student & P-value \\
\hline Intercept & -.824 & .187 & - & -4.406 & .000 \\
Ownership & .124 & .047 & .219 & 2.623 & .010 \\
Crisis & -.031 & .048 & -.054 & -.656 & .513 \\
Bank size & .046 & .016 & .241 & 2.867 & .005 \\
\hline
\end{tabular}

As we can observe from the results of Table 12, while crisis has not significant impact on LR, ownership and bank size have positive and meaningful effects on LR. Similar results are executed on the same data where $\mathrm{LR}_{\mathrm{BB}}$ is the dependent variable and Table 13 demonstrates the results as follows,

\section{Table 13}

The results of regression analysis for the first model when $L_{B B}$ is dependent variable (RSquare $=0.052$ )

\begin{tabular}{lccccc}
\hline Variable & \multicolumn{2}{c}{ Non-standard coefficients } & \multicolumn{2}{c}{ Standard coefficients } \\
& $\mathrm{B}$ & Standard dev. & B & t-student & P-value \\
\hline Intercept & -1.966 & .430 & & -4.571 & .000 \\
Ownership & .021 & .108 & .016 & .189 & .850 \\
Crisis & -.028 & .110 & -.022 & -.259 & .796 \\
Bank size & .102 & .037 & .234 & 2.744 & .007 \\
\hline
\end{tabular}

The results of Table 13 indicate that only bank size maintains important effect and two other factors, ownership and crisis, do not play important role on $\mathrm{LR}_{\mathrm{BB}}$. Another investigation is to consider CRzscore as dependent variable and Table 14 presents details of our findings,

\section{Table 14}

The results of regression analysis for the first model when CRz-score is dependent variable (RSquare $=0.012$ )

\begin{tabular}{lccccc}
\hline Variable & \multicolumn{2}{c}{ Non-standard coefficients } & \multicolumn{2}{c}{ Standard coefficients } & \\
& $\mathrm{B}$ & Standard dev. & B & t-student & P-value \\
\hline Intercept & 3.075 & .709 & & 4.337 & .000 \\
Ownership & -.056 & .179 & -.027 & -.316 & .753 \\
Crisis & -.157 & .181 & -.074 & -.866 & .388 \\
Bank size & -.049 & .061 & -.070 & -.808 & .420 \\
\hline
\end{tabular}

The results of Table 14 also indicate that none of the independent variables has any meaningful impact on CRz-score. Finally, we have investigated the impact of dependent variables on CR and found out that none of them had any meaningful impact on CR.

\section{Conclusion}

In this paper, we have performed an empirical investigation on measuring the effect of some Iranian banks on two credit risk factors. The proposed study has used Pearson correlation tests to investigate the relationships. We have also considered some linear regression models, where three variables of banks size, ownership and financial crisis are considered as independent variable and different risk factors were considered as dependent variable. The results of regression analysis have indicated that while crisis has not significant impact on LR, ownership and bank size had positive and meaningful effects on LR. In addition, only bank size maintained important effect on $L_{\mathrm{BB}}$ and two other factors, ownership and crisis, did not play important role on $\mathrm{LR}_{\mathrm{BB}}$. Finally, we have investigated the impact of dependent variables on $\mathrm{CR}$ and found out that none of them had any meaningful impact on $\mathrm{CR}$. 


\section{Acknowledgment}

The authors would like to thank the anonymous referees for constructive comments on earlier version of this paper.

\section{References}

Cifuentes, R., Ferrucci, G., \& Shin, H. S. (2005). Liquidity risk and contagion. Journal of the European Economic Association, 3(2-3), 556-566.

Dičevska, S. (2012). Credit risk - creating system of credit risk management in changing economic conditions in Macedonian banks. Procedia - Social and Behavioral Sciences, 44, 460-469.

Fiordelisi, F., Marques-Ibanez, D. \& Molyneux, P., (2010). Efficiency and risk in European banking. Working Paper NO 1211, European Central Bank.

Lando, D. (2009). Credit risk modeling. Handbook of Financial Time Series, 787-798.

Michalak, T.C., \& Uhde, A. (2012). Credit risk securitization and bank soundness in Europe. The Quarterly Review of Economics and Finance, 52(3), 272-285

Salas, V., \& Saurina, J. (2002). Credit risk in two institutional regimes: Spanish commercial and savings banks. Journal of Financial Services Research, 22(3), 203-224.

Wong, T.C., Hui,T. C., \& Huang, M. X. (2008). Assessing credit risk of companies with meanreverting leverage ratios, Working Paper, HKIMR 4. 